\title{
Fifty Years of Parker and Hulme: A Survey of Some Major Textual Representations and Their Ideological Significance
}

\author{
JAMES BENNETT \\ University of Newcastle, Australia
}

The murder of Honora Rieper ${ }^{1}$ by her teenage daughter, Pauline Parker, and Pauline's friend, Juliet Hulme, in June 1954 is a case with few rivals in New Zealand criminal history. ${ }^{2}$ It attracted international media attention and became a cause célèbre in New Zealand. The luring of Honora to the murder site at Victoria Park on the hills surrounding Christchurch on the pretext of a social excursion, the murder weapon itself - a half brick lodged in a stocking - and the reported behaviour of the two girls following the crime, were all elements which fed into their subsequent demonization. This was a crime that scandalized a conservative provincial community; it was seen as a stain on its character and history, while both the murder and ensuing Supreme Court trial etched themselves permanently into the consciousness of many New Zealanders alive during the 1950s.

The Parker-Hulme case has also produced a long tradition of diverse texts - 'factual' and fictional, written and visual, narrative and performative, paper-based and electronic. The news media, popular crime writers, a psychiatrist, a playwright, filmmakers, scholars and various laypeople have all been sufficiently enticed by the significance of the case to provide their own accounts, but usually through very different eyes. ${ }^{3}$ The variability in these perspectives is in part a function of the shifting social lens used to filter history and the various ways in which the case has spoken to different generations. But different mediums, and radically different motivations of commentators, have also had an important impact on the ways in which the murder and its surrounding context have been represented. Some of these representations - notably print media reports and fictionalized accounts - were contemporaneous with the event. Others reached their public in the ensuing decades, with a particular concentration emerging in the early to mid-1990s. These accounts all variously attempted to overturn myths and distortions surrounding earlier versions. 
My own interest in researching and writing on this topic can be attributed to the involvement of Dr F.O. Bennett as a medical witness in the Supreme Court trial and as a consulting GP to Pauline ${ }^{4}$ prior to the murder on the recommendation of Henry Hulme. ${ }^{5}$ Dr Bennett (known to his family and friends as 'Os', an abbreviation of his middle name Oswald) was my grandfather. ${ }^{6}$ He died in 1976 before I reached political consciousness. Moreover, he was a man so immersed in his professional life that I scarcely knew him. Aside from his medical practice, my memory is of a man whose time was mostly divided between writing, amateur painting and his workshop at the back of my grandparents' Mt Pleasant home. I would first learn of his connection to the case in 1994 from Margaret Scott, my aunt, who brought to my attention Peter Jackson's filmic representation of the case, Heavenly Creatures, on a return visit from Melbourne where I was then living. At first, I was somewhat perturbed by the representation of Os as an awkward, vaguely malign doctor who portrayed homosexual behaviour as insidious. His articulation of the issue also struck me as an extraordinary paradox given my own gender position as a gay male. There would be a long gestation period before returning to this event with scholarly tools of analysis.

I became drawn to Jackson's representation, for it offered a useful vehicle in thinking through approaches to the study of history through film, which I had begun teaching at the University of Newcastle, New South Wales. Heavenly Creatures included a scene shot in Dr Bennett's original surgery at 56 Armagh Street in central Christchurch in which the GP medicalizes Pauline's sexuality. It gradually became clear that there were few remaining written sources to yield insights on his attitude to the case, much less the exact words used in his consultation with Pauline. At his request, all case notes had been destroyed immediately prior to his death in order to preserve patient confidentiality, and although he was a published author, none of his writings touched on this episode. His testimony at the Supreme Court trial recorded in court transcripts was thus the only substantive extant source for the filmmaker to draw on. The medicalization scene in Jackson's film formed the basis of a separate article ${ }^{7}$ wherein I consider the role of psychiatry and medicine as tools to contain, control and remedy deviance, and as a source of social commentary which was given at the time in aiding the interpretation of the murder.

My curiosity was also driven by the way in which the producers of any given text use sources to construct their accounts of the event. Many accounts contemporaneous with the murder were characterized by certitude in their documentation of the 'truth'. This included the pervasive portrayal of Pauline and Juliet's relationship as homosexual, which in turn was held to be axiomatic in explaining their 'diseased' state of mind. ${ }^{8}$ Psychiatrist Reginald 
Medlicott characterized their condition as folie à deux (communicated joint insanity) at the 1954 Supreme Court trial. This label, which was legally rejected, has been reproduced uncritically even in recent texts by some who have explored representations of the event, including Peter Calder's discussion of Heavenly Creatures. Calder describes the film as a 'genuine folie à deux with lesbian undertones'. ${ }^{9}$ Ann Perry's (née Juliet Hulme) vigorous contestation of the two protagonists' sexual identities portrayed in all of the textual representations raises important issues about sexual contingency in the 1950s. Indeed, almost all theorists of modern homosexuality distinguish between homosexual behaviour and homosexual identity. ${ }^{10}$ As Deborah Cameron and Don Kulick have cautioned, '[o]ur understanding of what is sexual, and what different ways of being sexual mean, is always dependent on the kind of discourse about sex that circulates in a given time and place.. ${ }^{11}$ The role of speculation in constructions of the case is even more evident when it is considered that Pauline Parker was a fleeting subject of the historical gaze, quickly disappearing again from its reach. Her identity is not widely known and nor has she ever made any public comment on her involvement in the case in 50 years. She can only be known through these textual representations, which tend to draw heavily on her diaries - a chronicle containing fact interspersed with make-believe. ${ }^{12}$

Given that the 1950s texts all pre-date the post-modern turn, it is not surprising that their producers show no awareness of authorial subjectivity or the elusive nature of certainty in the construction of historical narratives around a complex case. This point has been established by scholars such as Australian historian Kay Schaffer, who investigated the stories surrounding Eliza Fraser, a woman stranded at sea in the 1830s and then the central figure in a captivity narrative on what is now known as Fraser Island off the coast of present-day Queensland. ${ }^{13}$ She is the first recorded woman to have encountered Aboriginal people on the Australian colonial frontier. Schaffer found that all of the historical participants in the event, and later commentators, were 'caught inescapably in ideologies and modes of representation specific to their times.' ${ }^{14}$ What began therefore as a search for the 'truth' using the empirical tools of an historian metamorphosed into an examination of the Eliza Fraser stories for constructions of gender, class and race in Australian society - as 'loci for ideological representations and contestations of difference'. ${ }^{15}$ Similarly, this article recognizes Parker and Hulme as a site of ideological contestation, particularly in respect to issues of gender and sexuality. It is not concerned with advancing yet another version of the 'truth'. Instead, I propose to survey a range of significant texts in order to suggest how each is a cultural artefact of the period of its production. Consideration of epistemological issues, that is to say, how 
historical knowledge of the case has been constructed and reproduced in its various forms, will be central to the discussion.

All of the 1950s texts surveyed herein reflect a period in western society when there was a deep yearning for the restoration of security and order following the turbulence and social upheaval of the Second World War. The war had profoundly and permanently altered sexual mores. ${ }^{16}$ Accordingly, great stress was placed in post-war society on traditional gender roles, on upholding patriarchal authority and on consolidation of the nuclear family. ${ }^{17}$ Non-normative forms of masculinity and femininity - notably homosexuality - threatened to blur traditional gender boundaries. Individuals who fell outside the boundaries of social normality were labelled deviates and constructed as a threat to the stability of post-war society. Moreover, as some scholars have demonstrated, sexually active female adolescents were represented as a threat to patriarchal authority. ${ }^{18}$ In New Zealand, this fear suffused the Mazengarb Report produced by a Special Committee on Moral Delinquency in Children and Adolescents appointed by the National government of Sidney Holland. The concern with teenage female sexuality together with that over good and bad motherhood - a key preoccupation of social ideology of the day - was critical to the moral panic around juvenile delinquency that gripped New Zealand in 1954. The Parker-Hulme case would become entwined with the issues investigated by Mazengarb's Special Committee.

Although this is a subject the news media has revisited periodically for more than 50 years, it is news reports contemporaneous with the event in which I am most interested. Details of the Parker-Hulme case were widely reported in the New Zealand media as well as overseas. In fact, it attracted more interest from the British media than any other news story from New Zealand had for a long time. ${ }^{19}$ Television was a technology not adopted in New Zealand until the 1960s. It is likely that the case was widely reported on radio, but radio news bulletins were infrequent. The print media was thus the dominant means of disseminating news and information, and in the 1950s it was routine practice for the papers to carry detailed reporting of major criminal court cases. The voracious appetite of the public for such stories and the in-depth reporting of this trial prompted one witness, a Senior Inspector of Schools in Canterbury, to complain at a hearing of Mazengarb's Special Committee in 1954 that '[n]o unsavoury detail has been omitted' in press coverage. ${ }^{20}$

Julie Glamuzina and Alison Laurie have examined media reportage and sensationalized accounts of the trial, which invariably demonized the two adolescent girls, pathologized their criminal act and replicated the narrow 
dichotomy of 'mad' versus 'bad' used by legal counsel in the Supreme Court trial. ${ }^{21}$

Through a process of emphasis, selection, omission and distortion in headings and sub-headings as well as the emotive construction of photos, newspapers led their readers to draw particular conclusions about the character of the girls and the nature of their relationship. ${ }^{22}$ The linking of ideas in order to suggest cause and effect was another technique used. So, for example, a sub-heading of the Christchurch Press, 'Homosexuality and Insanity', was a way of naming their 'pathology' and a key symptom. ${ }^{23}$ They were popularly portrayed as 'sexual perverts', and by extension they could then be constructed as capable of committing the most heinous of crimes - including murder. ${ }^{24}$ One of New Zealand's most eminent short story writers and novelists, Frank Sargeson, who was forced to conceal his own sexuality, recorded his revulsion in private correspondence at the 'press persecution' of the accused as well as the Hulme family. Sargeson was concerned with the publication of a malign image by the Auckland Star prior to the girls' conviction; an image that he felt was "calculated to produce feelings of disgust that such aplomb [Juliet's] could conceal such "depravity", ${ }^{25}$

Another notable example of journalistic practice in the case was to quote selective phrases or passages from Pauline's diaries, especially when it bore a relationship to the killing of Honora Parker. ${ }^{26}$ The diaries became the central exhibit in the Supreme Court trial and were frequently referred to by the prosecution as evidence of a premeditated murder plan. Problematically, the diaries did not simply document the everyday events in Pauline's life, but also the lavish interior world of game-playing and storytelling into which Pauline and Juliet retreated. The more they clashed with the exterior adult world, the more central that make-believe became in their respective lives. But as Sara Knox has commented, 'the persistent desire of the doctors, lawyers and successive generations of true crime writers to label Juliet and Pauline's complicated but adolescent fantasy game-playing symptomatic of their pathology is misguided, to say the very least'. ${ }^{27}$ While Pauline's diaries were a rare example of a documented murder plan, to read her shared imagined world with Juliet retrospectively as evidence of a pathological condition and murderous intent in the everyday world is an untenable conclusion.

Particular statements made by legal counsel or medical witnesses, which attempted to explain the crime through reference to the mental state of the girls, were seized on by the media and sensationalized. In his summing up, the Crown Prosecutor, Alan Brown, countered the defence argument of insanity with the charge that, 'This plainly was a coldly, callously planned and premeditated murder committed by two highly intelligent and perfectly 
sane but precocious and dirty-minded girls . . . They are not incurably insane. My submission is they are incurably bad'. ${ }^{28}$

The phrase 'dirty-minded girls' became one of the more notorious media headlines for the case, one that reverberated in the collective consciousness of readers. Words and phrases encapsulating madness (including 'paranoia' and its association with homosexuality) or badness were kept alive by their repetition in 'factual' and fictionalised accounts. ${ }^{29}$ Official reports also reinforced the view that the two protagonists were 'abnormally homosexual in their behaviour'. ${ }^{30}$ To have known Parker and Hulme and the social context of their circumstances beyond this public image became impossible for a contemporary audience. There were, however, rare exceptions to this emotive and frequently recycled phrase.

A valuable private counter-narrative, for instance, appears in one of the diaries of Charles Brasch, poet and founding editor of Landfall. A firm friend of the Bennett family, Brasch would stay at Armagh Street on his visits to Christchurch. In late August 1954, he was in town, became 'immersed in the atmosphere of the trial' and attended court on the morning of Saturday 28 August at the invitation of Dr Bennett. Brasch himself was a man of ambiguous sexuality. ${ }^{31} \mathrm{He}$ was severely critical of Brown's methods in the courtroom:

... he [Brown] dragged in every detail he could concerned with the sexual aspect of the case, almost gloating over it, as if to justify his foolish superficial phrase about 'a pair of dirty-minded girls'. It made me feel half ashamed to be listening, to be there at all. . . . Half his sexual detail was irrelevant \& proved nothing; at times he seemed floundering so badly I felt embarrassed for him. But couldn't help loathing him. ${ }^{32}$

Gendered norms and expectations also explain both the intensity and sensationalism of media accounts of the murder and ensuing trial. Indeed, this issue, along with the presumed pathology of the girls' relationship, were ideological foci for their demonization. The unusual nature of the crime itself was given emphasis in press headlines such as 'I Killed My Mother With A Brick'. ${ }^{33}$ Matricide is a very uncommon crime. Moreover, females have been culturally presented as passive, and as life-givers rather than life-takers. ${ }^{34}$ This is despite statistics which indicate that violent crime by women is more common than is generally realized. ${ }^{35}$ Helen Birch has noted the gendered expectation that males will express their anger in a more open and physical way, leading often to violence. Such an assumption does not apply to females, so that when they do kill, their behaviour is pathologized as either mad or bad. ${ }^{36}$ There is also a common and continuing association in the minds of many people (reinforced by Hollywood representations) 
of a link between lesbianism and violent women. ${ }^{37}$ Concern regarding this perceived linkage is central to the analysis of lesbian feminist academic Alison Laurie, whose critiques of artistic representations of the case will be discussed later.

Journalistic interest in the case was not confined to the detailed court reports which appeared in the print media during the Supreme Court hearing in August 1954. While the case was exploited by a number of other popular crime writers, Tom Gurr and Harold Cox's sensationalized potboiler Obsession merits particular scrutiny as it reproduces significant elements of legal and journalistic discourse framing the case. It was also penned by two men who were insiders to the working of the criminal justice system. Both were successful Australian newspaper men. Gurr, who was of English extraction, migrated from India, his birthplace, to New Zealand before finally settling in Australia in 1916, where he worked principally as a journalist and general manager of the Sydney Sunday Times. ${ }^{38}$ Together, Gurr and Cox published a chapter entitled 'Death in a Cathedral City' in a 1957 anthology called Famous Australasian Crimes that was reproduced in another murder anthology published over 30 years later. ${ }^{39}$ 'Death in a Cathedral City' was a forerunner to Obsession.

The central focus of Obsession is the Supreme Court trial, the arguments presented by legal counsel and the insanity defence. It has the hallmarks of a text inspired by Compulsion, a popular novelized account of the Nathan Leopold and Richard Loeb criminal trial in Chicago in the 1920s. Leopold and Loeb were two young Jewish men from moneyed backgrounds who were involved in a sexual relationship. They randomly murdered a boy named Bobby Franks. ${ }^{40}$ Had it not been for Leopold misplacing a pair of traceable spectacles near the victim's body, they might have committed the 'perfect crime'. A link was constructed between the two murder cases by Reginald Medlicott, key medical witness for the defence at the Supreme Court trial, as well as by the news media and popular crime writers. The New Zealand Observer, for instance, ran a feature story in early September 1954 claiming a parallel between Chicago and Christchurch ${ }^{41}$ Gurr and Cox reiterated the link in Obsession. They could find no other parallel for the malevolence of the case since Leopold and Loeb: 'All its tragic complexities - psychological, emotional, and, yes - intellectual - made it the crime of this era. Nothing like it had happened in the world since the famous "intellectual murder" by the university students, Leopold and Loeb, in Chicago thirty years earlier.' ${ }^{42}$

However, Glamuzina and Laurie have pointed to some significant contrasts between Leopold-Loeb and Parker-Hulme. ${ }^{43}$ One critical difference ignored by those who claimed the link or uncritically repeated it was that Leopold 
and Loeb did not face the threat of enforced and imminent separation from each other. Significantly, this was the central motivation in the murder of Honora Rieper.

The reader is able to gain an insight to what follows after glimpsing a summation of the case on the dust jacket of Famous Australasian Crimes, viz. 'one of the crimes of the century. ${ }^{44}$ In this text, Canterbury province and its capital, Christchurch, are located within the mythological framework of Arcadia, a place of natural abundance and prosperity - and one that is filtered through the eyes of class privilege, specifically the graziers of the Canterbury plains. The paradigm presented is unable to move beyond the imagining of Christchurch as a better Britain, a city characterized by 'tidy gutters' and 'tidy thinking' until 'the crime of the Murdering Girls struck . . . [the city] with cataclysmic force' ${ }^{45}$ To construct both girls as insane, an alien contagion in the midst of Arcadia, was a palatable and reassuring conclusion for the community to draw from their behaviour. In that way, malevolence could then be attributed to nature rather than the social environment of which they were a part. ${ }^{46}$

The disjunction between the lower-middle class background of the Riepers on the one hand and the Hulmes' securely upper-middle class circumstances on the other is a central tension in the social history behind this story. A further layer to that tension derived from the Englishness of Hilda and Henry Hulme and Honora Rieper. ${ }^{47}$ While 1950s Christchurch was already a stratified community, class tensions between the two families are likely to have been sharpened by the class-based experience of the parents in England. Pauline and her siblings Wendy and Rosemary were all New-Zealand-born, but Pauline yearned for the romance of her 'adopted' English (Hulme) family to break out of the monotonous, even hateful, existence which she felt entrapped her. Although Pauline is probably an exaggerated illustration of the point, nevertheless, for many New Zealanders in the mid-twentieth century, England continued to function as their imaginative 'home'.

A class perspective is further reinforced in 'Death in a Cathedral City' through the construction of a simplistic dichotomy in the behavioural and physical characteristics of Pauline and Juliet. While Pauline is described as 'a dark and dumpy girl, five feet three inches tall, with cold brown eyes gleaming watchfully from her olive-skinned face', Juliet has ' $[\mathrm{t}]$ he clear pink-and-white complexion of an English hedge rose . . Slanting grey eyes, the clear eyes of youth; high forehead; a slim and graceful body, and a confident air. Now she was intelligent and attractive. Soon she would be intelligent and beautiful. ${ }^{48}$

The authors rehearse arguments made by legal counsel and some of the medical witnesses at the trial, and thus readily succumb to a perspective 
which links Pauline's behaviour to the abnormal genetics of two of her siblings - a blue baby and a Down's syndrome child described rather crudely as 'a mongoloid, a flat-faced, drooling imbecile, who had been placed in an institution'. At the same time, Juliet's tuberculosis is deemed to be 'a disease found often in cases of sexual divergence'. ${ }^{49}$ Such descriptions reflect a time when it was commonplace to employ a racial classification when describing a mental disability; they also document a moment in time when the complex nature of sexuality was still poorly understood and social commentary was strongly influenced by Victorian values.

Obsession was published in the form of a 'documentary novel' with a clear didactic purpose. Such a categorization would suggest a blend of fact and fiction; a practice sometimes described today as 'faction'. The use of fictionalized names for the characters, unlike many representations of the case, helps to push the text to some extent into the fictional realm. Grant Morris has claimed that Obsession provides 'accurate and exhaustive historical detail about the trial based on actual transcripts' ${ }^{50}$ However, the uncompromising proclamation regarding the book's genre contained in the foreword raises numerous epistemological issues about our understanding of 'truth'. The following passage elucidates the authors' approach to the book and their conceptualization of the official documents informing the case:

... all the essential details of the crime are factual. Details of the planning of the murder, the murder itself, and the trial of the killers are sternly accurate. So are the entries quoted from the all-too-revealing diary of one of the girl murderers.

The strangest, the most incredible, and most terrible parts of this narrative are absolutely true. No novelist would have dared to invent these occurrences, these situations, these bizarre occasions.

The authors make no apology. Facts are facts. And all these facts, in the cold manner of police and court reports, are on the official record. ${ }^{51}$

On the first few pages of Obsession, the reader encounters a conversation aboard the Cook Strait ferry between a New Zealand Crown Prosecutor, George Cole, and an English engineer, Julian Aitken. The conversation is used to establish the social context of the era. 'Juvenile delinquency', a key term in the lexicon for classifying social deviance, is named and reference is made to the 'bodgie' - urban male youths who transgressed the normative moral code in their dress and behaviour. Cole comments that ' $[t]$ he juvenile delinquent is, of course, society's gravest problem of today. It's an aftermath, I think, of the partial breakdown of civilization between 1939 and 1945. ${ }^{52}$ This conversation also has relevance to a later discussion which links the two girls' sexuality with evil through reference to Nietzsche's philosophical 
tract, Beyond Good and Evil..$^{53}$ Gurr and Cox positioned their characters in relation to New Zealand's moral panic in 1954, which had tapped into linkages already made between homosexuality, delinquency and criminality. Homosexuality was not seen as a discrete phenomenon in the 1950s, but rather as one that was closely connected to a myriad of social problems arising from modernity. ${ }^{54}$

The novel also mirrors contemporary ideological notions of femininity. Even in the 1950s, lesbianism was little understood. Jill Matthews has argued that the practical invisibility of lesbians and the failure of medicine to comprehend the phenomenon can be explained by the "masculine bias of the gender order'. ${ }^{55}$ A fixation with the significance of penetrative sex whilst ignoring the possibility of emotional commitment (axiomatic to lesbian sexuality) led doctors and legislators to conclude that sexual relations were contingent on the presence of a penis. ${ }^{56}$ That issue in turn is refracted in the construction of Gurr and Cox's narrative. It is a narrative which reproduces a conventional post-war masculinist approach to the case and suggests men are threatened by the 'power' of Parker and Hulme in challenging heterosexual masculinity: ${ }^{57}$ 'One word seemed to be breathed incessantly in whispers that curiously became audible. Lesbians. The word was being spoken, too, in the washrooms of city offices and factories, together with the question that almost inevitably followed: "I've got a good idea of course, but just what is a Lesbian? I mean, what do they ...?", 58

As the discussion above suggests, Gurr and Cox drew substantially on arguments mounted by medical witnesses appearing for the defence in creating their texts. This is particularly so in respect to Reginald Medlicott's hypothesis of folie à deux. The ideological norms embedded in Obsession relating to gender and sexuality were entrenched in medicine, a profession at the height of its social status and power in New Zealand by the 1940s, and in psychiatry, a profession which had gained significantly in power and prestige during the war years. Accordingly, the discussion now turns to psychiatric literature informing the case.

Drs Medlicott and Bennett were both called as medical witnesses by defence counsel at the Supreme Court trial in August 1954. Bennett was the only medical witness to have interviewed Pauline both before and after the murder. His statement at the trial, reported verbatim in newspaper reports and reproduced in later fictionalized accounts, is the only published record of his view: '. . . it was a murder that was bestial and treacherous and filthy. It is outside all the kindly limits of sanity. It is a thousand miles away from sanity ... They are still not sane and in my opinion they never will be sane. ${ }^{59}$ 
His personal correspondence with his wife Pearl A. Bennett, who was attending a World Council of Churches conference at Evanston in the USA at this time, offers some interesting insights. At the trial, he took the stand to support the defence theory, developed by Medlicott, centred on paranoia of the exalted type in a setting of folie à deux. As both the accused had already signed confessions of their role in the murder, guilt or insanity were the only possible outcomes of the trial. Dr Bennett clearly believed the defence diagnosis to be correct, as he had earlier informed his wife on 8 July $1954 .{ }^{60}$ At the same time, he was aware that his report would be of no real assistance to the defence case. It is also apparent that he had one eye to the future: 'I'm very apprehensive about ... . [the trial]. I believe there are a number of foreign correspondents coming. The publicity glare will be fierce. The local glare doesn't matter, it's the historical one I fear. What they will go down in Law and Psychiatric journals for later generations to gibe at $\left[\right.$ sic]. ${ }^{61}$ This was both a prescient and highly ironic comment given the outpourings on the subject in psychiatric and law journals spanning several decades, many of which Dr Reginald Medlicott would author. ${ }^{62}$

Medlicott, who was medical superintendent at Ashburn Hall psychiatric hospital in Dunedin, was the medical professional most synonymous with the case. He interviewed both girls separately on a number of occasions after Pauline and Juliet had been taken into custody. His folie à deux theory was in part a pragmatic response to a legal dilemma, but Medlicott would continue to write and publish on the case for various periodicals, including the prestigious British Journal of Medical Psychology, for many years. Although he later altered his original diagnosis to 'adolescent megalomania', there was no fundamental change in his perspective on the Parker-Hulme case. ${ }^{63}$ Indeed, it remained something of an obsession for Dr Medlicott, who struggled to process what had happened in his own mind for the rest of his life. ${ }^{64}$ He later set out a detailed theory of the concept of evil, drawing on fiction, historical examples such as the Nazi Schutzstaffel (SS) and clinical case studies (including the Parker-Hulme murder) to support his argument. At the trial, he also raised the possibility of a genetic link to Pauline's criminality: '. . . her [Pauline's] younger sister is I understand a Mongolian imbecile at Templeton. The first baby died shortly after birth - I was told it was a blue baby and died within 24 hours. I consider that background raises a query as to the stock from which she came. ${ }^{65}$ When pressed by the prosecution to explain what he meant by his reference to 'defective stock', Medlicott refused to elaborate.

Medlicott interpreted the make-believe world of Pauline and Juliet described in the diaries as an assertion of their moral and intellectual 
separation from the rest of the community, a world in which they invoked 'their own paradise, their own god and religion and their own morality'. ${ }^{66}$ This view, coupled with the girls' exalted state in post-murder interviews, led Medlicott (and Bennett) into interpreting that behaviour as symptoms of a pathology, even though both were aware that the two girls were initially attempting to prove their insanity on pragmatic grounds. ${ }^{67}$ Every purported 'abnormality' - including their refusal to see Queen Elizabeth II on her Royal Tour of New Zealand - and every dishonest act, such as shoplifting, became evidence for the central theory advanced by the defence. Moreover, medical explanations were confined to the psychology of individual personalities rather than exploring the sociological context of their lives. ${ }^{68}$ Both doctors observed what they described as an extreme conceitedness and arrogance in the girls' demeanour, characteristics which were linked to a delusional world of grandeur. A key focus for that statement lay in the content of a poem called 'The Ones that I Worship' at the back of Pauline's diary containing the words heavenly creatures, a poem transcribed in one of Medlicott's articles.

Medlicott was also in 'no doubt' as to the homosexual nature of Pauline and Juliet's relationship. Furthermore, he postulated that homosexuality and paranoia were frequently associated. However, Dr Kenneth Stallworthy, appearing for the prosecution, disputed this link, submitting that in the thousands of patients he had seen in Britain and New Zealand, only the repressed homosexual exhibited signs of paranoia. ${ }^{69}$ At this juncture, it is helpful to consider the likely biases impacting on Medlicott's diagnosis of his subjects. Jill Matthews has argued that '[p]sychiatry is an institution very strongly implicated in the maintenance of the gender order in so far as it is concerned with "curing" deviation and restoring normality'. Three areas of life have been central to psychiatry's definition of normality: family life, sexuality and work. Deviance from normative patterns - expressed at the time as heterosexuality, monogamy and legality - was deemed to be, among other things, a 'failure of true femininity'. ${ }^{70}$ All three 'transgressions' were in evidence in the Parker-Hulme case and are cited in the literature by Medlicott. Indeed, it is difficult to see how his moral judgment would not have influenced the diagnosis. His subjects also did not behave in the manner to which a medical professional in the 1950s was accustomed, particularly given their age and gender. We know from Medlicott's report that in interviews he received a 'hostile and abusive reception' by each girl. ${ }^{71}$ The gender ideology embedded in Medlicott's analysis is apparent in the following passage comparing various cases for 'aspects of evil as a form of perversion': 'Bisexuality is exemplified almost throughout in gender confusion. No case achieved anything approaching mature heterosexuality, 
especially with the capacity to love and to be a parent in its full sense. Homosexual elements of either overt or covert nature could be found in most instances and women especially in their maternal role were despised. ${ }^{72}$ Medlicott's final published reference to Parker and Hulme appeared as a transcript of his key-note address to the 1985 Conference of the New Zealand Society on Sexology, some 30 years after the conclusion of the Supreme Court hearing, when public awareness of the case had begun to fade. ${ }^{73}$

At about the time this paper was published, the winds of change were about to exert an enormous impact on the socio-political landscape of New Zealand. A number of scholars and creative artists would soon be at work bringing representations of Parker and Hulme to new generations, viewed through very different eyes from the creators of 1950s texts. In the intervening three decades, New Zealand society had been transformed significantly not least by the new social movements which emerged during the late 1960s. These movements were concerned with improving people's lives and with forging new identities. In a recent major retrospective in the New Zealand Listener, historian Jock Phillips has argued that the protest against the 1981 Springbok rugby tour was a seminal moment in transition from the old to the new New Zealand. ${ }^{74}$ Another watershed would occur five years later on 9 July 1986 with the passage of the Homosexual Law Reform Bill. The legislation that was passed by the New Zealand Parliament following many months of acrimonious debate provided for decriminalization of private, consenting same-sex relations between males aged over 16 . Homosexuality had also shifted from a medical condition to a social identity with its own visible and distinctive sub-cultures. ${ }^{75}$ Medical, legal and social responses to non-normative sexuality had thus changed radically, and this shift is inflected in all of the texts on Parker and Hulme which emerged in the 1990s. One significant manifestation of the shift in textual representations was a nuanced discussion of the 'truth' and its relationship to this case.

Daughters of Heaven, a dramatized representation of the story written for the stage, is considered a significant text in the canon of New Zealand legal fiction. ${ }^{76}$ Written by American-born playwright, scriptwriter, fiction writer and editor, Michaelanne Forster, who has been domiciled in New Zealand since 1972, Daughters of Heaven premiered at the Court Theatre in Christchurch on 19 October 1991 and was directed by Elric Hooper, a doyen of the city's arts community. The play was subsequently staged in other major New Zealand cities. Forster has said that her representation does not try to 'find' Pauline or Juliet. Nor does it attempt to tell the story from their adolescent perspective. ${ }^{77}$

One of the play's key narrative devices is to employ a fictional character, Bridget O'Malley, the Irish housekeeper of the Hulmes. She performs the 
important function of a social chorus providing a link back to the sociopolitical context of the 1950s. This is a Brechtian dramatic technique to express community or socially-constructed views while avoiding identification with the protagonist. ${ }^{78}$ The device adds layering and nuance to the text. For example, referring to a production at Wellington's Downstage theatre, one reviewer wrote that the final scenes were highly ambivalent as "[s]ympathy for the "daughters" is both created and negated by the presence of Bridget'. ${ }^{79}$ The key sources informing Forster's narrative are courtroom testimony (including diary extracts) reported in the media and interviews with people who lived through the events. This tangled, contradictory and judgmental source of commentary, which formed an important part of the static surrounding public reception of the court case, finds voice in Bridget's character. In Forster's representation, the action pivots on the aftermath of the murder: namely, the trial, a 'classic dramatic construct', and the detention of Pauline and Juliet by the justice system. ${ }^{80}$ Psychiatric perspectives are also brought out through dialogue involving Reginald Medlicott.

The basic premise of Forster's work is to locate the 'psychological heart of the murder'. ${ }^{81}$ That point is echoed in the foreword to the text by Elric Hooper, who acknowledges not only the complexity of this story and its representation on stage but also the nature of the dramatic medium itself. Forster is much less concerned with presenting the audience with the 'truth' than she is in holding a mirror to the case and refracting notions of truth to her public. Again, Bridget is a key medium in facilitating this process. The following textual excerpts situated in the courtroom usefully illustrate this issue:

BROWN: Is this diary entry anywhere near the truth?

HILDA: It is nowhere near the truth. The entry is a work of fiction.

BROWN: Are you certain?

BRIDGET: You're telling the truth and pigs can fly, eh Hilda?

BROWN: Thank you Mrs Hulme.

BRIDGET: By now the courtroom was swimming in contradictions and useless talk. Dr Medlicott insisted Pauline and Juliet were certifiable and the Crown doctors said just the opposite. He said, she said, he said - and on and on it went . . . and were we any closer to the truth? Not in my book. ${ }^{82}$

Forster's probing of the truth in her text resonates with Foucault's principle of dispersal at the centre, namely ' $[\mathrm{t}] \mathrm{he}$ origin lies at a place of inevitable loss, the point where the truth of things corresponded to a truthful discourse, the site of a fleeting articulation that discourse has obscured and finally lost' $^{83}$ 
Peter Jackson's 1994 feature film Heavenly Creatures was released two years after Forster's production was first performed. ${ }^{84}$ Heavenly Creatures bestowed on Jackson mainstream credibility after his cult splatter flicks Bad Taste, Brain Dead and Meet the Feebles, which earned him the appellation 'Kaiser of Kiwi ketchup'. ${ }^{85}$ The film's narrative perspective centres around the girls' friendship and events are seen largely from their perspective. There is no equivalent of Forster's social chorus. Both Jackson and his partner Fran Walsh identified personally with the girls. Walsh first encountered demonizing accounts of the girls when she herself was a teenager and continued to be captivated with the story of Parker and Hulme and who they really were; Jackson is on record as saying that in many respects the two girls appeared to him as figures who belonged more to the $1990 \mathrm{~s} .{ }^{86}$ The murder is the beginning and end point of Jackson's film. It does not address the Supreme Court trial and legal argument which framed the case; however, it does interpolate some dialogue from court transcripts into the screenplay. Excerpts from Pauline's diaries, expressed using voice-over technique, are used as the principal vehicle for re-telling the story. As Heavenly Creatures is the work of a creative artist influenced by commercial imperatives, it cannot purport to be entirely 'truthful', nor has the filmmaker conceptualized his work as one grounded entirely in reality. Some recontextualizations and dramatized scenes, for instance, have departed from the 'reality' of the case. Nevertheless, Jackson does see his visual text as one which documents all of the essential details of the case. ${ }^{87}$ The filmmaker also used all of the original locations still accessible for filming to heighten the authenticity of his work, and he deliberately chose historical rather than fictitious names for all of the people connected with the events he portrays.

As it is a medium governed by the camera, narrative film constitutes a discourse distinct from written language, employing its own separate conventions and devices. Indeed, it is not always easy to reconcile a professional historian's conception of accuracy with visual language and its construction of a narrative. In his representation of the Parker-Hulme case, Jackson employs examples of what film historian Robert Rosenstone has classified as 'true invention'. Whilst this term may strike the reader as an oxymoron, it is nevertheless a useful concept in thinking through the implications of how history is presented on celluloid. The cinematic image contains great specificity of detail; where sources yield insufficient evidence to fill out the narrative and visual detail accurately, the film maker must invent. True invention engages the historical discourse surrounding the context of a given event in contrast with false invention, which distorts and falsifies history ${ }^{88}$ The fictional device of compression, so necessary to film makers, is also used in Heavenly Creatures to allow the story to fit a dramatic 
structure. In my view, Jackson and Walsh, who wrote the screenplay, have presented an understanding of the event which is substantially faithful to the Parker-Hulme case whilst managing to fulfil the imperative of all commercial cinema, that it must entertain its audience. It is not a mere artistic flight of fancy divorced from the essential detail of the historical event. My main reservation concerns aspects of the visualization of Pauline and Juliet's interior world and the conflation of reality with make-believe. Jackson's visual text vividly realizes this elaborate imagined world centred on the Kingdom of Borovnia inhabited by plasticine characters, some of whom have a predisposition to violent acts. The interweaving of scenes set in Borovnia with the reality of 1950s Christchurch has sometimes been read by audiences as a sign of madness in the actions of the girls. An alternative reading of these sequences is that the filmmaker is critiquing social conformity and peeling away the layers of a hidebound 1950s community.

To achieve that effect, particular attention is reserved for the doctor - a key agent of social normality. In this way, the film makes an important statement about the role of medicine and psychiatry in the 1950s. The medical intervention is set in train during a dramatic sequence of scenes in which Dr Hulme spies the two girls curled up asleep together in bed at Ilam. Hulme is first alerted to their 'wayward tendencies' when he glances at the rear-view mirror in his car and catches sight of the two girls sitting in the back seat with clasped hands. As he anxiously declares to the Riepers one dark, stormy night, contrived for dramatic effect: 'Your daughter appears to have formed a rather unwholesome attachment to Juliet . . . It's the intensity of the friendship that concerns me ... I think we should avert trouble before it starts ... If Pauline is indeed developing in a rather wayward fashion, Dr Bennett is the ideal man to set her back on track. ${ }^{89}$

Hulme's class-based strategy is to intervene using his power and social prestige. ${ }^{90}$ The central 'problem' of homosexuality is able to be isolated in the less privileged girl who must be controlled and remedied by referral to the physician. ${ }^{91}$ The camera then cuts to the surgery in a scene more humorous than disturbing, due to Jackson's adroit caricature of the medical man. The Kiwiana in the doctor's surgery - that is, the 'Be a healthy Kiwi' poster on the wall - is used as a device to reinforce the point that the ideology of the contemporary medical profession linked a healthy mind and body. The portrayal of adults in Heavenly Creatures - above all, the vicar and the doctor - in such an exaggerated and darkly humorous way is at once a filtering of the world through the lens of the two teenagers who see adult figures of authority as a central source of their alienation, as well as a clue to the screenwriters' manifest empathy with the protagonists. The net effect 
is a 'normalising' of the characters of Pauline and Juliet, counterbalanced by an abhorrence of their ultimate act.92

Parker and Hulme: A Lesbian View by Glamuzina and Laurie remains the only book-length scholarly analysis of the case. ${ }^{93}$ Their research into the case began in 1986, and was supported by a grant received the following year from the Social Sciences Research Fund Committee that acknowledged the significance of the case. Glamuzina and Laurie do not claim to provide the 'truth' of the case; rather, theirs is 'one account and interpretation... from a lesbian [feminist] perspective'. ${ }^{94}$ Not only do they interrogate the heteronormative bias framing earlier accounts by foregrounding gender and sexuality, but they also position their discussion firmly within a socialpolitical context. Unlike many earlier accounts which placed the burden of explaining the murder squarely on the psychology of the "two Christchurch girls', linked to their deviant sexuality, they look for a much broader and more meaningful context. ${ }^{95}$

Social forces shaping the culture inhabited by the two girls - including their family environments - are thus of critical concern to both scholars. This approach, which draws on questionnaires with a small sample of lesbians who lived through the 1950s, has enabled them to document the seminal significance of the event in the construction of a lesbian identity in New Zealand. They note the contradictory effects of the case. On the one hand, Laurie and Glamuzina note that the emotive, distorted and sensational depiction of the case, particularly in reports carried by the news media, had serious repercussions for women with same-sex feelings, a trend that endured until the 1970s. The publicity surrounding the case also caused girls' schools and parents to become very watchful of same-sex friendships and the intensity of their expression. On the other hand, Laurie and Glamuzina report accounts from a few New Zealand lesbians who felt there was no other person in the world with feelings like themselves until they had met other lesbians or heard about Parker and Hulme, the negative associations of the case notwithstanding. ${ }^{96}$ For both authors, the Parker-Hulme cause célèbre was an important catalyst in their journey to understand both the construction and invisibility of past subaltern identities. Their objective was to deconstruct the 'powerful ideology' which had governed the case for so long. ${ }^{97}$

It could be argued that the aims of Glamuzina and Laurie on the one hand, and Jackson and Walsh on the other, very broadly coincided. In both cases, there was a determination to overturn the distortions and mythology pervading the case in many earlier representations, as well as a desire to treat the two girls and their relationship sympathetically. In other respects, their motivations differed significantly. Alison Laurie has been 
sharply critical of Jackson and Walsh's visual text on a number of grounds, although the principal objection lies in her claim that this is a film whose narrative is predicated on Medlicott's defence plea of folie à deux. She also contends that Heavenly Creatures merely adds to the long-established theme of 'lethal lesbians' in celluloid stories, and that the case becomes situated within a context of 'murderous deviancy and anti-lesbianism'.98 She is particularly unsettled by the truth claims made by its auteur. This response is prompted in part by her experience of student audiences reading the filmic representation as factual: 'Many viewers undoubtedly regard the fictionalized dialogue, characters and events produced from the imaginations of Jackson and Walsh as authoritative'. ${ }^{99}$ Furthermore, Laurie is troubled by the ethics of creative artists producing representations of the event using the historical names of Pauline Parker and Juliet Hulme, especially while the two protagonists are still alive.

Whilst I do not wish to minimize the importance of the issues Laurie raises or simply to dismiss her criticisms of the film, she is nevertheless moved more by the politics of representation rather than by an interest in the capacity of the film to offer an historical interpretation within the limitations of the dramatic film medium. Glamuzina and Laurie believe that Pauline and Juliet had a lesbian relationship; at the same time, they recognize the difficulties inherent in using this term even in the mid-twentieth century. Yet some who have interpreted their argument do not discuss the important issue of sexual contingency in the 1950s, namely, the wide gulf that existed between sexual behaviour and sexual identity. B. Ruby Rich's introduction to the 1995 edition of their book is a case in point. ${ }^{100}$ Moreover, in Parker and Hulme: A Lesbian View, the authors employ a Maori spiritual perspective to interpret a diary entry by Pauline on the girls' vision of the Fourth world at Port Levy on Banks Peninsula where the Hulmes owned a holiday house. This diary entry became critical to the insanity plea mounted by the defence. Glamuzina and Laurie consulted a tohunga (scholarly priest) from Puaui (in the Port Levy area) who considered that Honora's killing may have represented a 'sacrifice' to a 'powerful spiritual force'. They found this account 'compelling and helpful', as a spiritual dimension was absent from previous accounts. ${ }^{101}$ However, this strikes me as both tangential to the major issues of gender and sexuality raised by the case, and an eminently contestable proposition.

In conclusion, this article has surveyed some of the most significant textual representations of the Parker-Hulme case in a variety of different mediums over the past half century by drawing on interdisciplinary perspectives. Space does not permit discussion of all texts relevant to the case, such as those which cite the event as part of a much broader discussion of social 
history. All texts - regardless of their medium - are implicated in the culture and ideologies of the time of their production, as Kay Schaffer's work on the Eliza Fraser stories has demonstrated. One of the major shifts evident between texts of the 1950s and the 1990s is the realization that psychology and psychiatry alone cannot provide an adequate explanation of the murder of Honora Rieper. A socio-political framework for interpreting issues surrounding the event is evident in some measure in all of the 1990s texts. The way in which the surveyed texts have positioned themselves in relation to the 'truth', a key thread in the discussion, is also an important marker of the period of their production. The 1950s texts - whether popular crime writing, journalism or psychiatric literature - tend to present a picture of certitude, an unproblematic notion of the 'truth' in a case that was significantly influenced by speculation and bias arising from ideological norms, particularly those governing gender and sexuality. The 1990s texts reflect varying degrees of awareness of authorial subjectivity and the elusive nature of the 'truth'. Gendered, heteronormative and class bias embedded in earlier representations is also critiqued in the 1990s accounts, revealing a significant shift in the socio-political complexion of modern New Zealand. That is not to say that these more recent representations are entirely unproblematic and cannot themselves be contested. Indeed, the discussion on Heavenly Creatures in particular demonstrates the contestability of using a dramatic film to represent a 'truthful' account of an historical episode such as this. The potential for multiple audience readings of any given text renders the relationship between authors and their subject matter and dissemination of the 'truth' a complex process. All of these texts - including my own - feed into Parker and Hulme as a site for ideological contestation on a number of fronts. This has been and will continue to be so on account of the social and political significance of the case. It was, after all, the most public moment in 1950s New Zealand involving the perception of a homosexual relationship, and a relatively rare documented occurrence of the crime of matricide.

1 Following the revelation by the police that Herbert and Honora Rieper were not legally married, Pauline was charged under the name Pauline Yvonne Parker. Thereafter they became 'Pauline Parker' and 'Mrs Parker' in media references.

2 I have many debts to acknowledge in the research and writing of this paper. I would particularly like to thank the University of Newcastle, New South Wales, and the University of Auckland for research grants to support this work. Jennifer Frost, Chris Brickell and Lyndall Ryan all read earlier versions and contributed valuable insights and suggestions. Margaret Scott and Karl Stead provided me with some valuable references to material on the case in the Brasch papers in the Hocken Collections, and my access to them was facilitated by Anna Blackman and Alan Roddick. I am also much indebted 
to my colleagues Jocelyn McKinnon, Marguerite Johnston and Caroline Webb at the Ourimbah campus of the University of Newcastle, who formed an interdisciplinary research group with me to analyse Heavenly Creatures in the early stages of the project. This contributed some critically important perspectives in thinking through the many layers of the film as a text. Alison Laurie, Simon Booth, James Belich, Jonathan Bennett, Gerald Bennett, Sara Buttsworth, Derek Dow, Kathleen Hollobon, Brian Paltridge, John Scott, students in my history and film courses, and various members of conference and seminar audiences made useful suggestions or provided me with helpful references. My appreciation is also extended to the relevant research institutions: Archives New Zealand (Wellington and Christchurch offices), the Alexander Turnbull Library, the National Library of New Zealand, the New Zealand Film Archive (Wellington), the Macmillan Brown Library at the University of Canterbury and the Hocken Collections at the University of Otago.

3 Internet sites featuring detailed discussions of the case and some of its representations are one significant textual form. Although I do not propose to discuss internet sites for the purpose of textual analysis, I have nevertheless used some as a source for my argument. Important examples include 4th World: The Heavenly Creatures website by Adam Abrams based on research by John D. Porter, http://www.geocities.com/Hollywood/studio/2194/, and Tod Lippy's Heavenly Creatures interview with Peter Jackson and Frances Walsh, www.tbhl.theonering.net/peter/interviews/walsh_jackson.html. Another useful and detailed resource can be found on the website of Christchurch City libraries. See http://www. library.christchurch.org.nz/Heritage/Digitised/.

4 For the most part, I refer to Pauline Parker and Juliet Hulme by their first names in order to avoid confusion with other members of the Parker and Hulme families who are also discussed in the article.

5 Henry Rainsford Hulme was Rector of Canterbury College from 1948 to 1954. He was also an eminent physicist who was later appointed Chief of Nuclear Research in the British post-war atomic research programme at Aldermaston. For further details about Hulme, see W.J. Gardner, E.T. Beardsley and T.E. Carter, A History of the University of Canterbury, 1873-1973, Christchurch, 1973, especially pp.319-21 and 361-4.

6 For biographical details, see the entry by Geoffrey Rice on F.O. Bennett in The Dictionary of New Zealand Biography, Vol. Five, Wellington, pp.54-55; and Bennett's autobiography, A Canterbury Tale, Wellington, 1980.

7 James Bennett, 'Medicine, Sexuality and High Anxiety in 1950s New Zealand: Peter Jackson's Heavenly Creatures (1994)', Health and History: Journal of Australian and New Zealand Society of the History of Medicine, 8, 2 (2006), pp.147-75.

8 See Julie Glamuzina and Alison J. Laurie, Parker and Hulme. A Lesbian View, Auckland, 1991, especially p.88.

9 Peter Calder, 'Would-Be Warriors. New Zealand Film since The Piano', in Jonathan Dennis and Jan Bieringa, eds, Film in Aotearoa NZ, 2nd ed., Wellington, 1996, p.187. The case is similarly constructed by Pennie Hunt in her discussion of photographer Ann Shelton's 'psychic landscape', Doublet, Parker-Hulme crime scene, Port Hills, Christchurch, New Zealand, 2001. Diptych, C-type prints. Doublet is from a series of works by Shelton called Public Places. See Pennie Hunt, 'From the University Collection', The University of Auckland News, 30 June 2006, p.7.

10 Annamarie Jagose, Queer Theory, Dunedin, 1996, p.15. For a detailed discussion of sexual contingency in the Parker-Hulme case, see Bennett, 'Medicine, Sexuality and High Anxiety in 1950s New Zealand'.

11 Deborah Cameron and Don Kulick, Language and Sexuality, Cambridge, 2003, especially p.10. Similarly, Jeffrey Weeks has argued that '[s]exuality is as much about language 


\section{Fifty Years of Parker and Hulme}

as it is about the sexual organs'. Jeffrey Weeks, Against Nature: Essays on History, Sexuality and Identity, London, 1991, p.3.

12 As advised by Archives New Zealand, I applied for permission to view the ParkerHulme file through the Department for Courts. The request was considered by a High Court Judge who granted me permission to read the file, but denied access to view the diaries. According to the High Court, previous requests 'by others' to view the diaries had also been declined. No grounds for refusal to view the diaries were provided. Email correspondence from Helen Vermeulen, Criminal Jurisdiction Manager, High Court, Christchurch to author, 23 February 2003. I was, however, assisted considerably by the published work of Glamuzina and Laurie who were granted full access to the diaries and quoted from them extensively. This helped to overcome reliance on court transcripts and quotations from the media. See J. Glamuzina and A. Laurie, Parker and Hulme, Ithaca, New York, 1995, pp.10-11 and especially chapter 5.

13 Kay Schaffer, In the Wake of First Contact: The Eliza Fraser Stories, Melbourne, 1995.

14 Schaffer, In the Wake of First Contact, p.19.

15 Ibid., pp.9, 16 and 19.

16 George Chauncey, Jr., 'The Postwar Sex Crime Panic', in William Graebner, ed., True Stories from the American Past, New York, 1993, pp.175-6. Chris Brickell explores this point in a New Zealand context. Brickell, 'Sex Instruction and the Construction of Homosexuality in New Zealand, 1920-1965', Sex Education, 5, 2 (May 2005), pp.119-36.

17 Maureen Molloy, 'Science, Myth and the Adolescent Female: The Mazengarb Report, the Parker-Hulme Trial and the Adoption Act of 1955', Women's Studies Journal, 9, 1 (March 1993), especially pp.2-3. On this point, see the essay entitled 'The Woman Problem' by renowned New Zealand writer A.R.D. Fairburn. Fairburn expressed anxieties at the subversion of traditional gender roles by an 'alliance' of homosexual men and feminist women using the device of 'homosexual-feminist propaganda'. Ironically, Fairburn supported homosexual law reform despite these publicly-stated attitudes. A.R.D. Fairburn, The Woman Problem and Other Prose, Auckland, 1967.

18 See, for example, Molloy, 'Science, Myth and the Adolescent Female', especially pp.20-21.

19 Star Sun, 28 August 1954.

20 6N2, Special Committee on Moral Delinquency in Children and Adolescents, 1953-54, Hearings, 30 August - 7 September 1954, MS Papers-2384-03, Alexander Turnbull Library. Similarly, the Premier of New South Wales, J.J. Cahill, complained in the NSW Legislative Assembly that press reporting of the trial had gone 'far beyond the bounds of decency'. Reported in Press, 4 September 1954, p.7. At the same time, there was an insatiable public appetite in New Zealand for every morsel of information about the case. Bill Pearson summed up the paradox thus: 'We are the most puritan country in the world, yet we love a dirty story'. See Bill Pearson, Fretful Sleepers and Other Stories, Auckland, 1974, p.10. I am indebted to Chris Brickell for drawing this reference to my attention.

21 See, for example, Evening Post, 31 August 1954, reporting coverage of the case in the Melbourne Argus.

22 Examples from reporting in the Christchurch Press include: 'Insidious Onset', 26 August 1954; and 'Wild Infatuation', 27 August 1954.

23 Press, 28 August 1954, cited in Glamuzina and Laurie, Parker and Hulme, 1991, p.114. 


\section{Journal of New Zealand Studies}

24 This was a common phenomenon in the western world in the post-war era. For instance, George Chauncey Jr. notes that the print media in the United States tended to conflate sexual deviancy by lumping all acts of deviance (whether consenting adult homosexual relations or a 'sadistic murderer of children') under the same category of sex 'deviate'. This had particularly negative consequences for the public reception of homosexual men in the sense that consenting adult same-sex relations were frequently aligned with paedophilia and other sex crimes. See Chauncey, 'The Postwar Sex Crime Panic', pp.170 and 177. The connection in this case was later established in popular crime writing on the case by popular writers such as Gerald Sparrow. Julie Glamuzina and Alison J. Laurie, 'Sexual Politics in the 1950s: The Parker-Hulme Murder Case', Sites, 19 (Spring 1989), p.39. Gerald Sparrow, Queens of Crime, London, 1973.

25 Sargeson linked the Parker-Hulme case to the official government enquiry published as the Mazengarb Report, which was centrally concerned with the outbreak of teenage 'sexual delinquency' in Lower Hutt. He considered this to be 'prurient prying into children's behaviour'. In September 1954, the poet Allen Curnow made the Mazengarb Report the subject of one of his long-running humorous and satirical verses published under the pen name Whim Wham every Saturday in the Press and New Zealand Herald. Entitled 'Modesty's a Good Thing Too', he took a similar line to Sargeson:

$\therefore$. They face each other in the Field,

The Knight of Modesty, with Shield

Of natural Understanding steeled,

Against the Dragon Badness-

... The snooping Prurience that smutches

With smutty Breath each Bloom it touches,

Takes youth in its unyouthful Clutches,

And stings itself to Madness.'

Sargeson to Brasch, 16 October 1954, Charles Brasch: Literary and personal papers, MS0996-002/346, Hocken Collections, Dunedin. Also see Terry Sturm, ed., Whim Wham's New Zealand. The Best of Whim Wham 1937-1988, Auckland, 2005, pp.108-9.

26 Glamuzina and Laurie, Parker and Hulme, 1991, pp.114-15.

27 See Sara Knox, 'Heavenly Games: Retelling the Parker-Hulme Case', Meanjin, 54, 4 (1995), p.682.

28 See trial reports, Evening Post, 28 August 1954, p.12; and Press, 30 August 1954, p.12.

29 See, for example, Tom Gurr and H.H. Cox, Obsession, London, 1958, especially pp.163-4, 176, 182-83, 238, 242; and Tom Gurr and H.H. Cox, 'Death in a Cathedral City', in Famous Australasian Crimes, London, 1957, pp.163-4.

30 Report of the Special Committee on Moral Delinquency in Children and Adolescents, Appendices to the Journal of the House of Representatives, H-47, 1954, see especially pp. 8 and 20. The committee's report, produced for the government in time for the 1954 general election, was distributed to every household in the country which received the family benefit.

31 See Margaret Scott, Recollecting Mansfield, Auckland, 2001, especially pp.111-21.

32 Brasch diary, Saturday 28 August 1954, MS-0996-009/023, Charles Brasch: Literary and personal papers (ARC-0124), Hocken Collections.

33 Evening Standard, 16 July 1954, cited in Glamuzina and Laurie, Parker and Hulme, 1991, p.113.

34 This issue is discussed in some detail in Glamuzina and Laurie, Parker and Hulme, 1995, especially pp.134-9. 
35 Candice Skrapec has observed that women are responsible for about 12 to $15 \%$ of all murders in the United States 'over time'. This approximates the rate of female perpetration of serial murders. She also cites research on serial murder offenders and victims by criminologist Eric Hickey. His sample study of 203 offenders revealed a slightly higher rate of female offending than the above figures. See Candice Skrapec, 'The Female Serial Killer: An Evolving Criminality', in Helen Birch, ed., Moving Targets: Women, Murder and Representation, London, 1993, p.243.

36 This dichotomy is discussed at length in Glamuzina and Laurie, Parker and Hulme.

37 See Helen Birch, 'Introduction'; Christine Holmlund, 'A Decade of Deadly Dolls: Hollywood and the Woman Killer'; and Skrapec, 'The Female Serial Killer', especially pp.4-5, 149, 267, in Birch Moving Targets. One of the most recent examples was the successful Hollywood feature film Monster (Patty Jenkins, USA, 2003) based on the life of convicted serial murderer, Aileen Wuornos, who also had a lesbian relationship.

38 Brief biographical details of Gurr can be found at www.austlit.edu.au/browse. His papers are held at the State Library of New South Wales. ML MSS 795.

39 R.G. Jones, Killer Couples, London, 1989, pp.249-68. For a detailed list of popular crime writing which drew on the Parker-Hulme case, see Laurie and Glamuzina, Parker and Hulme, 1991, pp.117-20.

40 As with Parker and Hulme, the Leopold-Loeb case captured the imagination of various writers and film makers. The award-winning playwright and novelist, Meyer Levin, had his fictionalized version Compulsion published in 1956. This was adapted in 1959 in a film of the same name directed by Richard Fleischer starring Orson Welles. Alfred Hitchcock's 1948 feature film Rope is loosely based on the Leopold-Loeb story. A much more recent representation is to be found in the stylish feature film Swoon (Tom Kalin, USA, 1992). Swoon highlights the influence of early twentieth-century medical pathologies.

41 See K.R. Hancock, 'Christchurch and Chicago. Two Crimes that Shocked the World!', New Zealand Observer, 8 September 1954, pp.6-7; Gurr and Cox, Obsession, pp.5, 95; R.W. Medlicott, 'Paranoia of the Exalted Type in a Setting of Folie à Deux. A Study of Two Adolescent Homicides', British Journal of Medical Psychology, 28, 4 (1955), pp.205-23; and R.W. Medlicott, 'Some Reflections on the Parker-Hulme, Leopold-Loeb Cases with Special Reference to the Concept of Omnipotence', New Zealand Law Journal, 37 (1961), pp.345-8.

42 Gurr and Cox, Obsession, Foreword.

43 Glamuzina and Laurie, Parker and Hulme, 1995, pp.127-8.

44 In Obsession, the same authors label the crime 'the world's most appalling essay in personal violence for thirty years'. See Gurr and Cox, Obsession, p.152. Similarly, it was portrayed by another popular crime writer as 'the most dreadful crime of the century'. See Rupert Furneaux, Famous Criminal Cases, 2, London, 1955, pp.33-47.

45 Gurr and Cox, 'Death in a Cathedral City', p.149. The most recent work on the history of Christchurch can be found in John Cookson and Graeme Dunstall, eds, Southern Capital. Towards a City Biography 1850-2000, Christchurch, 2000. Unfortunately, there is no mention of the Parker-Hulme case. Omission of the Hulmes from a chapter discussing the Christchurch élite suggests that the author may need to employ a more flexible definition in discussing this concept as many in Christchurch of the 1950s saw the Hulme family as part of a social élite. It also raises the question of how outsiders to the city should be seen in relation to this élite.

46 I am indebted to Jennifer Frost for this insight.

47 Herbert Rieper was the only non-English parent. He was born in Tasmania, Australia. 


\section{Journal of New Zealand Studies}

48 Gurr and Cox, 'Death in a Cathedral City', pp.149 and 152.

49 Ibid., pp.151 and 165.

50 Grant Morris, 'New Zealand Law in Literature and Legal History: A Survey of Legal References in New Zealand Historical Fiction', ANZLH E-Journal (2005). Accessed 1 May 2006 at: www.anzlhsejournal.auckland.ac.nz/Morris.pdf.

51 Gurr and Cox, Obsession, pp.5-6.

52 Ibid., p.11.

53 Gurr and Cox are likely to have been influenced by Medlicott's discussion of Nietzsche as analogous to Parker and Hulme with particular reference to the 'cult of the superman' phenomenon. Compare Medlicott, 'Paranoia of the Exalted Type', especially p.220, with Gurr and Cox, Obsession, p.47.

54 For a more detailed argument, see Brickell, 'Sex Instruction', especially pp.121 and 130. Also see NZ Pictorial, 12 December 1955, cited in Glamuzina and Laurie, Parker and Hulme, 1991, p.150.

55 Jill Julius Matthews, Good and Mad Women: The Historical Construction of Femininity in Twentieth-Century Australia, Sydney, 1984, p.118.

56 Matthews, Good and Mad Women, p.118. That same perspective is echoed in the response of Juliet Hulme. Glamuzina and Laurie note, '[w]hen questioned directly by the defence psychiatrist about whether they had a sexual relationship, Juliet seemed surprised and said "But how could we? We are both women".' Department of Justice, Notes of Evidence, p.97, cited in Glamuzina and Laurie, Parker and Hulme, 1995, p.65. Also see Chris Brickell, 'Writing Homosexual Histories: The Use of "Sex Instruction", in Alison J. Laurie and Linda Evans, eds, Outlines: Lesbian and Gay Histories of Aotearoa, Wellington, 2005, pp.37-47.

57 I am grateful to Lyndall Ryan for this observation.

58 Gurr and Cox, Obsession, p.158.

59 Notes of Evidence, Regina v Parker and Hulme, Transcripts of Supreme Court Proceedings, CH273/T10/1954, 138, Archives New Zealand (Christchurch Regional Office).

60 F.O. Bennett to Pearl A. Bennett, 22 August 1954, MS 127, Box 6, Folder 1, F.O. Bennett Papers, Macmillan Brown Library, University of Canterbury.

61 Ibid.

62 Notable examples include: Medlicott, 'Paranoia of the Exalted Type in a Setting of Folie à Deux'; Medlicott, 'Some Reflections on the Parker-Hulme, Leopold-Loeb Cases'; R.W. Medlicott, 'An Examination of the Necessity for a Concept of Evil: Some Aspects of Evil as a Form of Perversion', British Journal of Medical Psychology, 43 (1970), pp.271-80.

63 Medlicott, 'Some Reflections on the Parker-Hulme, Leopold-Loeb Cases', especially p.347. A detailed analysis of Medlicott's articles as well as other medical and psychiatric perspectives is provided in Glamuzina and Laurie, Parker and Hulme, 1995, pp.120-33.

64 I am indebted to Sir John Scott for this observation.

65 See Notes of Evidence, Regina v Parker and Hulme, Transcripts of Supreme Court Proceedings, CH273/T10/1954, 58 and 178, Archives New Zealand (Christchurch Regional Office). Templeton Hospital and Training School, located on the outskirts of Christchurch, provided for the institutional care of psychopaedic (intellectually disabled) patients in the main, although it also admitted some people of broadly average intelligence in its early years of operation as a direct result of central government's 1920s eugenics policy, 
which sought to quarantine the so-called 'feeble-minded' from the general population lest they breed.

66 Notes of Evidence, Regina v Parker and Hulme, Transcripts of Supreme Court Proceedings CH273/T10/1954, 64, Archives New Zealand (Christchurch Regional Office).

67 See Glamuzina and Laurie, Parker and Hulme, 1995, p.123, and Medlicott, 'Paranoia of the Exalted Type', p.216.

68 Glamuzina and Laurie, Parker and Hulme, 1995, pp.93, 132.

69 All the medical witnesses who took the stand at the trial, Drs Medlicott and Bennett for the defence, and Drs Stallworthy, Saville and Hunter for the prosecution, characterized the relationship as 'homosexual'. Their interpretation of the way in which the relationship manifested itself varied considerably. See Notes of Evidence, Regina v Parker and Hulme, Transcripts of Supreme Court Proceedings, CH273/T10/1954, 58 and 178, Archives New Zealand (Christchurch Regional Office). For a recent scholarly perspective on homosexual identity, see Chris Brickell, 'The Emergence of a Gay Identity', in A. Kirkman and P. Moloney, eds, Sexualities in Aotearoa/New Zealand, Dunedin, 2005.

70 Matthews, Good and Mad Women, pp.24, 113 and 177.

71 Medlicott, 'Paranoia of the Exalted Type', p.222.

72 Medlicott, 'An Examination of the Necessity for a Concept of Evil', p.274.

73 See Reginald Medlicott, 'Concepts of Normality and of Moral Values', New Zealand Sexologist (March 1986), pp.2-8. Medlicott still believed homosexuality was a deviation from 'biological normality'.

74 Jock Phillips, 'A Nation of Two Halves', New Zealand Listener, 8-14 July 2006, pp.12-19.

75 See Cameron and Kulick, Language and Sexuality, p.76. This issue is discussed with particular reference to male homosexuality in Justin McNab, 'Gay Sub-Culture in New Zealand: A Social and Political Movement', in Claudia Bell, ed., Community Issues in New Zealand, Palmerston North, 1997.

76 Morris, 'New Zealand Law in Literature and Legal History', p.137.

77 Forster quoted in Heavenly Creatures website by Adam Abrams. See 6.1 'Daughters of Heaven', accessed 3 May 2006 at: www.geocities.com/Hollywood/studio/2194.

$78 \mathrm{I}$ am indebted to Jocelyn McKinnon for this insight. Elric Hooper describes Bridget as 'a being in whom are gathered together opinions, attitudes and facts manifested in the city at the time.' See Hooper, 'Foreword', in Michaelanne Forster, Daughters of Heaven, Wellington, 1992.

79 Judith Dale, 'Daughter (W)rite 1. Daughters of Heaven at Downstage - Two Views', Illusions, 20 (Summer 1992), pp.20-23. A more critical perspective on Forster's work can be found in Alison Laurie, 'Daughter (W)rite 2. Daughters of Heaven at Downstage - Two Views', Illusions, 20 (Summer 1992), pp.24-25.

80 Morris, 'New Zealand Law in Literature and Legal History', p.136.

81 Hooper, Foreword in Forster, Daughters of Heaven, p.8.

82 Forster, Daughters of Heaven, pp.49-50 and 75.

83 Michel Foucault, 'Nietzsche, Genealogy, History', in Donald F. Bouchard, ed., trans. Donald F. Bouchard and Sherry Simon, Language, Counter-Memory, Practice, Ithaca, New York, 1977, p.143.

84 A more detailed discussion of the film can be found in Bennett, 'Medicine, Sexuality and High Anxiety in 1950s New Zealand'. 


\section{Journal of New Zealand Studies}

85 Barry Keith Grant, A Cultural Assault: The NZ Films of Peter Jackson, Nottingham, 1999, p.1.

86 Evening Post, 13 October 1994, p.25. It is worth noting some of the camera work in the film has the effect of emphasizing the gulf between Jackson's present - the 1990s - and the past. The most tangible illustration of this point is the zooming in on the mouth of Dr Hulme and, in a subsequent scene, on Dr Bennett, as each struggles to enunciate the word 'homosexuality'.

87 See Todd Lippy's Heavenly Creatures interview with Peter Jackson and Frances Walsh, accessed 7 October 2003 at: www.tbhl.theonering.net/peter/interviews/walsh_jackson. html.

88 Robert Rosenstone, Visions of the Past: The Challenge of Film to our Idea of History, Cambridge, Mass., 1995, pp.64-76.

89 Heavenly Creatures (Peter Jackson, New Zealand, 1994). Emphasis added.

90 Forster also addresses class-based tensions in her playscript. In the following excerpt she employs Bridget as social chorus to demonstrate how Henry Hulme was able to mobilize class privilege and social prestige to his own advantage: 'The court in its wisdom decided that Dr Hulme was too important to be bothered with trivial matters like murder. He'd snuck off to England well before the trial. But they dragged Mr Rieper into the box - him with his wife bashed by his own daughter. Now that's British justice for you.' Forster, Daughters of Heaven, p.70.

91 There was likely to have been little if any positive literature available to doctors at this time. A rare exception was Alfred Kinsey, whose ground-breaking survey on human female sexuality was published in 1953 to a largely hostile and disbelieving American public. This reveals the very clear limits to 1950s' awareness and tolerance of same-sex relations.

92 Tod Lippy's Heavenly Creatures interview with Peter Jackson and Frances Walsh, accessed 7 October 2003 at: http://tbhl.theonering.net/peter/interviews/walsh_jackson. html.

93 Other New Zealand scholars have also discussed the case in their work. They include Redmer Yska, All Shook Up: The Flash Bodgie: and the Rise of the New Zealand Teenager in the Fifties, Auckland, 1993; and Maureen Molloy, 'Science, Myth and the Adolescent Female'. Although published in the 1990s, Yska's book echoes the scandalized tone of many 1950s' accounts of the events surrounding the case.

94 Alison J. Laurie, 'Heavenly Images', Journal of New Zealand Studies, 1 (October 2002), p.147.

95 Glamuzina and Laurie, Parker and Hulme, 1995, p.132.

96 Ibid., see especially pp.165, 169 and 179.

97 Ibid., p.169. They note that while portrayals of male homosexuality in the 1950s through cultural forms such as film were universally negative, images of lesbians were completely invisible in New Zealand at this time. See Glamuzina and Laurie, Parker and Hulme, 1995 , p.163.

98 Laurie, 'Heavenly Images', p.147.

99 Laurie, 'Heavenly Images', p.137, and Alison J. Laurie, 'Heavenly Images - a Lesbian View of Peter Jackson's Film Heavenly Creatures', presented to Film and History Conference, Victoria University of Wellington, 2000, p.6. The supertitles on a black screen at the beginning of the film permit this interpretation. The viewer is informed that '[d]uring 1953 and 1954 Pauline Yvonne Parker kept diaries recording her friendship with Juliet Marion Hulme. This is their story. All diary entries are in Pauline's words.' This information claims a much closer relationship to the 'truth' than the standard supertitle 


\section{Fifty Years of Parker and Hulme}

prefacing historical films, viz. 'based on a true story' - a phrase which can be read in multiple ways. See Frances Walsh and Peter Jackson, Heavenly Creatures screenplay, p.2. Jackson's biographer has claimed that 'much of the criticism that can be directed at Heavenly Creatures would be rendered meaningless if they had prefaced the movie with the far safer words "based on a true story" or changed the names of Juliet and Pauline'. See Ian Pryor, Peter Jackson: From Prince of Splatter to Lord of the Rings, Auckland, 2003, p.160.

100 B. Ruby Rich, 'Introduction', in Glamuzina and Laurie, Parker and Hulme, 1995, see especially p.x.

101 Glamuzina and Laurie, Parker and Hulme, 1995, pp.62-63 and 147-9. 